Ненад Нинковић

Универзитет у Новом Саду

Филозофски факултет

Одсек за историју

nenadninkovich@yahoo.com
Оригиналан научни рад

примљено: 24. мај 2012

прихваћено: 1. октобар 2012

\title{
ЦРКВЕНО-НАРОДНИ САБОР И АРХИЈЕРЕЈСКИ СИНОД ИЗ 1749. ГОДИНЕ
}

Сажетак: После смрти митрополита Исаије Антоновића, 22. јануара 1749. остао је трон Карловачке митрополије после само пет месеци поново упражњен. Епископи су одмах почели да припремају нови црквено-народни сабор, одлучивши да администрирање у време седисваканције по трећи пут повере бачком епископу Висариону Павловићу. Царски комесар барон генерал Христијан фон Хелфрајх отворио је Сабор 23. јула 1749., а два дана касније изабран је нови карловачки митрополит карлштадски владика Павле Ненадовић. Поред избора митрополита Сабор је донео низ корисних одлука за српски народ, нпр. основан је Клирикални фонд, оснажена Монашка правила митрополита Вићентија Јовановића, затим је донето прво Саборско устројство и упућене тужбе владару. Решавање питања дугова, епископских посвећења, права постављања администратора итд. такође су нашло место на њему. Паралелно са Сабором радио је и Архијерејски синод, на коме су донете важне одлуке за духовни живот, али и у вези са проблемом редукције епископија.

Кључне речи: Црквено-народни сабор, Архијерејски синод, митрополит Павле Ненадовић, комесар Христофер фон Хелфрајх, саборско устројство, редукција епископија, народне тужбе.

Црквено-народни сабори представљали су најзначајнији вид српске аутономије у Хабзбуршкој монархији признат још Првом привилегијом цара Леополда I. ${ }^{1}$ Генезу ове институције могуће је пратити од времена постојања српске средњовековне државе, преко сабора у Османском царству до њеног посебног облика који добија у Хабзбуршкој монархији. Током прве половине XVIII века она је претрпела знатне промене, носећи у себи део дотадашње традиције, а примјући под утицајем Беча обрисе Земаљског сабора (Landtag), што никад у потпуности није

\footnotetext{
* Текст је настао као фазни резултат рада на пројекту Војвођански простор у контексту европске историје (број 177002) Министарства просвете и науке Републике Србије.

${ }^{1}$ Дејан Микавица, Владан Гавриловић, Горан Васин, Знаменита документа за историју српског народа 1538-1918, Нови Сад 2007, 15-17.
} 
постала. ${ }^{2}$ Сабори су били места у којима се расправљало и одлучивало о најважнијим политичким и духовним питањима српског народа, места са којих су упућивани захтеви владарима, или на њихове одговарано, те скуп који је бирао првојерархе Карловачке митрополије. У почетку одржавани без тражења владарске дозволе, чешће расправно-политичког него изборног карактера, све више се институцијализују чему кључно доприносе царски комесари који на њим спроводе владарску вољу, ослањајући се кад год је то могуће на унутарсрпска неслагања. Све до промена које је делатношћу Светозара Милетића и политичара који су поникли у његовом окружењу или из његове странке, донела друга половина XIX века у српску црквено-школску аутономију, ${ }^{3}$ изглед ових Сабора није пуно мењан, а основе његовог устројства настале у дотадашњој пракси, дефинисане су на црквенонародном сабору из 1749. На њему су донете и друге битне одлуке, као што је основање Клирикалног фонда, организовање митрополиских финансија, формирање органа који уз митрополита треба да брине о народним пословима и чува српске Привилегија, решавање питања попуњавања упражњених епископија, али и укидања појединих.

Питањем историје Сабора из 1749. бавило се у прошлости неколико аутора, од којих су најзапаженији Милутин Јакшић и Димитрије Руварац. Најстарији текст у вези са овим сабором оставио је Д. Руварац у својој књизи Српски народни и ирквено-народни сабори у Угарској1889. где је сажето изложио избор новог митрополита и проблем који се појавио у вези са будимсим посланицима. ${ }^{4}$ Новим сазнањима о овом сабору Милутин Јакшић је 1902. обогатио српску историографију у тексту Два српска сабора, који је изшао у пет наставака у Богословском гласнику, а у којем је аутор изложио радњу црквено-народних сабора из 1748. и 1749. ${ }^{5}$ Јакшић је први пут приказао ток Сабора из 1749, али готово половину његовог рада чини текст који говори о другим питањима осамнаестовековне црквене политике. ${ }^{6}$ Руварац је 1925. објавио грађу о овом Сабору, која је у великој мери била познат Јакшићу, $^{7}$ што га је навело да упути оштру и исхитрену критику Руварцу. ${ }^{8}$ После поменуте двојице аутора бавио се овим сабором др Душан Љ. Кашић који је објавио извор значајан за техничку припрему сабора, са већ познатим, списком посланика. 9

\footnotetext{
${ }^{2}$ Исидора Точанац, Српски народно-ирквени сабори (1718-1735), Београд 2008, 243.

${ }^{3}$ Дејан Микавица, Политичка идеологија Светозара Милетића, Нои Сад 2006, 155-178; Исти, Српско питање на Угарском сабору, Нови Сад 2011, 156-160.

${ }^{4}$ Димитрије Руварац, Српски народни и ирквено-народни сабори у Угарској и и. к. и к. повереници на юима од 1690 до данас, Земун 1889, 17-18.

${ }^{5}$ Милутин Јакшић, Два српска сабора (1748 и 1749), Богословски гласник, Књига I, Сремски Карловци 1902, 26-39, 92-104, 172-184, 243-251. и 314-320.

${ }^{6}$ Објашњавао је историју северинске епископије, монашких правила Вићентија Јовановића и радњу Архијерејског синода из 1750. (Милутин Јакшић, Два српска сабора..., 180-184, 248-250. и 317-320.)

7 Димитрије Руварац, Дозвола за држање народног сабора 1749. Српски Сион, број 16, Сремски Карловци 1906, 442-443; Исти, Српски Народни Сабор 1749., Споменик Српске краљевске академије LXII, други разред, 51, Земун 1925, 119-137.

${ }^{8}$ Милутин Јакшић, Д. Рувараи, Српски Народни Сабор 1749..., 160-161.

9 Душан Љ. Кашић, Посланици на нродно-ирквеном сабору 1749. у Карловцима, Зборник за историју Матице српске, књига 2, Нови Сад 1970, 96-105.
} 
На крају треба поменути и кратак, али изванредан текст проф. др Александра Форишковића у Историји српског народа. ${ }^{10}$

\section{Припрема сабора}

Новоизабрани митрополит Исаија Антоновић упутио се 1748. из Сремских Карловаца, преко Арада, чији је епископ до тада био, и Будима, за Беч. Већ у Будиму његово здравствено стање било је веома лоше, па иако су га ту и у Бечу лечили најбољи доктори, болест се погоршавала и митрополит је 22. јануара 1749. преминуо. Тако је трон Карловачке митрополије, после свега пет месеци, поново био упражњен. ${ }^{11}$ По већ устаљеној пракси одмах су епископи и угледни појединци почели да предузимају неопходне кораке како би Црква и даље нормално функционисала и како би се добила дозвола за сазивање новог сабора. У том циљу већ су на митрополитовом погребу у Будиму пакрачки епископ Софроније Јовановић и карлштадски Павле Ненадовић са игуманом Теодосијем Веселиновићем, будимским бировом Петром Димићем, ешкутом Петром Кнежевићем и капетаном Стеваном Заком, закључили да се Царици мора послати трочлана делегација, која би тражила дозволу за сазивање сабора. О свом закључку послали су обавештење у Карловце, како би се овде архијереји састали са виђенијим људима и изабрали делегацију, као и администратора седисвакантне митрополије. Док је вест о смрти митрополита стигла у Карловце и док су обавештења о потреби састанка послата у њега су стигли и епископи Јовановић и Ненадовић те се 1/12. марта 1749. овде састао Синод, којем су поред архијереја присуствовали представници Војне границе. Радио је само један дан, али је донео битне закључке, пре свега решење по којем је епископ бачки Висарион Павловић постављен за администратора, што је био његов трећи пут на овом положају. Избор чланова депутације која би тражила сазивање сабора није прошао без расправе. Наиме, постоје два акта са истим датумом која садрже имена депутираца, у једном су депутирци одређени као и за Сабор из 1748. владика пакрачки Софроније, који је фигурирао као посланик у оба акта, потпуковник петроварадинског хусарског пука Рајко Прерадовић и биров српског темишварског магистрата Маленица Јосифовић. ${ }^{12}$ Могуће је да се ишло за тим да би иста депутација као за претходни

\footnotetext{
${ }^{10}$ Александар Форишковић, Политички, правни и друштвени односи код Срба у Хабзбурикој монархији, Историја српског народа, IV-1, Београд 1994, 272-273.

${ }^{11}$ Милутин Јакшић, Два српска сабора..., 98-101.

${ }^{12}$ На основу потписа и печата са овог документа могуће је утврдити ко је присуствовао овом скупу у Карловцима. Били су ту од епископа владика бачки Висарион, темишварски Георгије и карлштадски Павле, затим пуковник Атанасије Рашковић, потпуковник Секула Витковић, потпуковник Вук Исаковић, управник поште Андреј Андрејевић, бездински архимандрит Теодосије Веселиновић, игумани крушедолски Леонтије и хоповски Захарије, те два протопрезвитера Живан Црногорац карловачки и Арсеније Живковић сегедински. Иако га овде нема, на пуномоћју се налази и потпис пакрачког епископа Софронија, што је чудно јер је сам био члан депутације. Из других аката овог Синода јасно је да му је пакрачки епископ присуствовао. (Архив Српске академије наука и уметности у Сремским Карловцима, Митрополијско-патријаршиски архив, фонд „А“ (у даљем тексту АСАНУК, МПА „А“) 311/1749, 312/1749. и 314/1749.)
} 
сабор, услед дотадашњег искуства, лакше извршила поверени задатак. Разлог за промену представника Провинцијала могао је бити тај, што он 1748. није ни стигао у Беч, те је својим поступком угрожавао читаву акцију, али је непознато из ког је ралога замењен Прерадовић. ${ }^{13}$ Уместо њих одређено је да у Беч иду потпуковник Поморишке војне границе Јован Шевић и будимски ешкут Симеон Андрејевић. ${ }^{14}$ Синод је решио и питање администрирања упражњеним епископијама. У ово време још нису биле попуњене ни вршачка и арадска које су избором за митрополита Исаије Антоновића остале упражњене, док је смрћу владике Василија Димитријевића децембра 1748. иста судбина задесила и будимску епархију. Донето је решење по којем се администрирање арадском епископијом даје владици Павлу Ненадовићу, ${ }^{15}$ будимском, како је то пред смрт одредио митрополит Исаија,

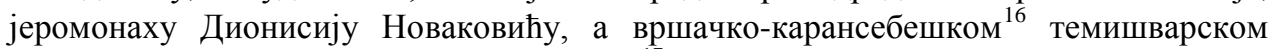
владици митрополиту Георгију Поповићу. ${ }^{17}$

Без претходне молбе депутација је стигла у Беч и без обзира што ни овај пут, као ни 1748. није поштована процедура добила је дозволу да поднесе своје захтеве царици Марији Терезији. ${ }^{18}$ У решењу које је издала владарка, наглашено је да се њихов поступак сада толерише, али да ће у будуће све делегације које буду долазиле морати да поштују прописану процедуру писмене најаве ради чега долазе, на коју морају имати позитивну дозволу. У супротном не само да неће бити саслушани већ ће бити протерани из Беча. Што се тиче главног захтева за сазивање сабора царица му је изашла у сусрет и 9. маја преко Илирске дворске депутације донела решење по којем би се сабор требало да састане у Карловцима и то у броју од 75 посланика, по 25. из сваког сталежа, духовног, војног и грађнског, а за свог комесара је одредила барона генерала Христијана фон Хелфрајха, петроварадинског команданта. Владарка је сматрала да се не сме поновити пракса која је постојала

\footnotetext{
${ }^{13}$ У ово време је већ народни секретар био синовац будућег митрополита Ненадовића-Павле Ненадовић. (АСАНУК, МПА „А“ 317/1749.)

${ }^{14}$ У прилог томе да је вођена расправа о посланицима иде и чињеница да је у оба документа остављено празно место на којем би требало да стоје имена посланика Војне границе и Провинцијала. Они су уписани касније, мастилом друге боје, када је ово питање решено. (АСАНУК, МПА „А“ 311/1749. Димитрије Руварац, Дозвола за држање народног сабора 1749, 442.)

${ }^{15}$ АСАНУК, МПА „А“ $314 / 1749$.

${ }^{16}$ На Синоду који је радио после избора Исаије Антоновића за епископа одређено је да за вршачкокарансебешког епископа буде презентован Владарки епископ посвећења Јован Георгијевић. Једно од последњих дела митрополита Исаије било је његово презентовање Марији Терезији 13/24. јануара 1749. али због митрополитове смрти није потврђен, већ се на ту одлуку чекало до маја 1750. (АСАНУК, МПА „Б“ 168/1750; Милутин Јакшић, Два српска сабора..., 99-100.)

${ }^{17}$ Синод је поред ових битних потеза за нормално функционисање цркве донео и одлуку која се тицала православне црквене општине у Бечу. У одлуци је оштро претио због непоштовања црквеног устава коју је донео за бечку општину Светог Георгија патријарх Арсеније IV. Опомену је упутио још митрополит Исаија, а Синод је сада нагласио да им опраштају досадашње преступе, али да будуће неће толерисати, већ најстроже казнити. (АСАНУК, МПА, „Б“, 38/1749.)

${ }^{18}$ Још је из времена патријарха Арсенија IV постојала наредба по којој су Срби смели слати народним пословима неку депутацију у Беч тек када за то писменим путем затраже и добију дозволу. Ова наредба је постојала и у време седисваканције иза патрјархове смрти и прекршена је приликом рада на сазивању сабора 1748. (Милутин Јакшић, Два српска сабора, 26-28.)
} 
приликом последњег сабора, да се посланици о свему договоре раније у скупштинама које сами држе без присуства комесара. ${ }^{19}$ Зато је нагласила да се посланици у саборну просторију могу појавити тек када за то звона најаве време, али ова наредба није поштована. ${ }^{20}$ Наиме, забележено је у регистру аката Карловачке митрополије да је Сабор ${ }^{21} 8 / 19$. јула 1749 , четири дана пре званичног отварања, обавезао будућег митрополита без обзира ко буде изабран на то место да „...nрофесора Дионисија Новаковића за будимског епископа консекрира и презентира““, о чему ће бити више речи напред. ${ }^{22}$

Док је за Сабор из 1748. у владарској дозволи за његово одржавање, стајало да број посланика буде умерен као на Сабору из 1744. тачан број од 75 посланика који ј одређен владарским решењем из 1749. постао је пракса за касније, са изузетком Темишварског ${ }^{23}$ и Благовештенског. ${ }^{24}$ Посланици су бирани по епископијама, при чему се пазило да то буду најугледнији људи. ${ }^{25}$ У зависности од величине дијецезе зависио је и број посланика које су слали, али и њихова структура. ${ }^{26}$ Пред почетак Сабора у Карловце је стигло 32. представника духовног сталежа, исти број представника грађанства и 26 представника граничара. Укупно деведесет посланика, петнаест више од броја који је прописан. Због овога су појединци избрисани из спискова, али не сви прекобројни, већ је прихваћено да у радњи сабора учествује 79. посланика. ${ }^{27}$ Највише посланика је било из сремске и бачке епископије, а најмање из костајничке и карлштадске. ${ }^{28}$ Сабору су

\footnotetext{
${ }^{19}$ Милутин Јакшић, Два српска сабора, 32.

20 АСАНУК, МПА „А“ 348/1749; У овом акту стајала је поменута наредба о процедури доласка депутације у Беч и обавезном писменом пријављивању. (Димитрије Руварац, Дозвола за држање народног сабора 1749, 442-443; Милутин Јакшић, Два српска сабора, 172-174.)

${ }^{21}$ Овде је у протоколу употребљена реч цео, сав сабор (gesamt-укупан, сав; Gesamter National Congress) док је касније употребљаван израз сабрани сабор (versammeln-скупљени, сабрани; Versamelten National Congress), како се први израз више не понавља, а из других акта је познато када је комесар отворио сабор, произилази да је под Gesamter National Congress подразумеван неки вансаборски састанак посланика. (АСАНУК, МПА „А“ 347/1749, 348/1749, 349/1749.)

${ }^{22}$ Односно да га хиротонише и презентује Марији Терезији. (АСАНУК, МПА „А“ 348/1749.)

${ }^{23}$ Владан Гавриловић, Темишварски сабор и Илирска дворска канцеларија (1790-1792), Нови Сад 2005, 112-113.

${ }^{24}$ Димитрије Руварац, Српски народни и ирквено-народни сабори у Угарској, 18; Милутин Јакшић, Два српска сабора, 31.

${ }^{25}$ Милутин Јакшић, Два српска сабора, 31-32.

${ }^{26}$ Димитрије Руварац, Српски Народни Сабор 1749., 119-121.

27 Од 15. монаха избрисана су двојица, од 17 представника свештенства тројица, а од 32. представника грађанства шесторица. Укупно, дакле једанаест посланика није приступило раду сабора. Избрисани су реметски игуман Атанасије и бођански Јоасаф, шидски протопрезвитер Гаврил Кириловић, бачиначки свештеник Михајло и поп Лацко из Великог Варада, затим, Јаков Влашић из Илочког дистрикта, Пантелејмон Миланковић сенатор (из Бачке епископије), Никола Ђуричко и Никола Кандеци (или Кондеци) обојица сенатоти из Темишварског владичанства, Михајло Јакшић капетанлојтнант из Острогона и Петар Божић из Ирига, али не сремског већ из Будимске епархије. (АСАНУК, МПА, „А“ 351/1749. Димитрије Руварац, Српски Народни Сабор 1749., 119-121; Милутин Јакшић, Два српска сабора, 174.)

${ }^{28}$ Димитрије Руварац, Српски Народни Сабор 1749., 119-121; Душан љ. Кашић, Посланиции на народноирквеном сабору $1749 . . ., 98-99$.
} 
присуствовали следећи епископи: бачки Висарион Павловић, темишварски митрополит Георгије Поповић, карлштадски Павле Ненадовић, пакрачки Софроније Јовановић и епископ посвећења Јован Георгијевић. ${ }^{29}$ Све укупно било је 84. посланика. Међу представницима војничког сталежа налазили су се најзначајнији српски команданти у Монархији од којих је по звању најстарији био пуковник Атанасије Рашковић, затим су ту били потпуковници Секула Витковић, Вук Исаковић, Јован Хорват, Михајло Прерадовић, капетани Јован Поповић, Стефан Зако, Арсеније Ђулинац, Јоаникије Антоновић (брат покојног митрополита Исаије), Димитрије Михаиловић, Живан Шевић итд. Био је ту и млади Симеон Пишчевић, у то време поручник. ${ }^{30}$

\section{Саборске радње до инсталирања митрополита}

Комесар је званично отворио Сабор 12/23. јула 1749. после извођења прописаног церемонијала. Најпре је уследила провера посланичког пуномоћја, а онда је комесар одржо говор који је у ствари садржаво царичину дозволу за сазивање и рад сабора, одлуку о његовом постављању за комесара, те задацима Сабора, који би требало да изабере новог митрополита. У говору је истакао које би карактерне особине требало да има, а при самом звршетку говора оставио је Сабору рок од три дана да изабере новог митрополита. ${ }^{31}$ Вероватно је тражио од сабора да састави саборско устројство или је и сам понудио решење у том правцу. Извесно је, међутим, да је Сабор о томе расправљао првог дана. ${ }^{32}$ Саборско устројство је донето, како стоји у српској варијанти документа која је се чини старијом, на основу већ устаљене праксе. ${ }^{33}$ Српска варијанта је имала тринаест, а немачка, која је и уписана у саборски протокол десет тачака. Разлика је настала услед тога што у српској варијанти постоји део којег нема у немачкој и што су у српској одредбе нешто разрађеније те због тога подељене у више глава. У првом члану, српске варијанте објашњава се поступак избора депутације која би тражила сазивање сабора. Предвиђено је да се она бира на погребу митрополита, било од стране окупљеног народа и јерархије, било од стране администратора митрополије уз дозволу сабраног народа. Епископи са администратором чекају да им депутација пошаље обавештење о комесару са којим се договарају о датуму почетка рада сабора. Овај део недостаје у немачкој, коначној варијанти саборског устројства, јер

\footnotetext{
29 У актима која су настала током и непосредно по завршетку овог Сабора не помиње се нигде костајнички епископ Алексије Андрејевић, који је умро у новембру 1749. Један документ из августа исте године упућује на закључак да није присуствовао сабору, јер је 4 (15). августа 1749. забележено шта је све епископ дао у залог „господару Гаји Попићу“ за свој дуг (сакос, митру, мали и велики панагијар, сребрни нож, две сребрне чаше, оковани крст са стопом, сребром везени појас, епитрхиљ са сребрним дугмадима и голпију са сребрним ланцем). Веродостојност копије овог документа марта 1750. гарантовао је гомирски архимандрит Данило Јакшић. (АСАНУК, МПА, „Б“, 4б/1749.)

${ }^{30}$ Д. Руварац, Српски Народни Сабор 1749..., 119-121.

31 Димитрије Руварац, Српски Народни Сабор 1749., 122.

${ }^{32}$ АСАНУК, МПА „А“ 350/1749.

${ }^{33}$ Милутин Јакшић, Два српска сабора, 174.
} 
се њиме кршила ранија одлука о томе ко има да постави администратора удове митрополије. Наиме, у српском тексту се нигде не помиње право владара да то учини, већ се то искључиво право народа. И ова одредба је била по угледу на дотадашњу праксу написана, али без уважавања или без знања да је пар месеци раније (19. априла 1749.) донета одлука на предлог грофа Коловрата, по којој је само владар надлежан да постави администратора упражњеног митрополијског трона. После Ненадовићевог избора и Сабор је прихватио овакво решење. ${ }^{34}$

Коначним текстом који је усвојен на Сабору може се сматрати немачки, записан у Протоколу. Суштинске разлике између ова два текста, осим у горе поменутом, нема. У њему је описана цела процедура од тренутка када посланици дочекају комесара уз предвиђену војну параду, до инсталације новоизабраног митрополита. $^{35}$ После дочека комесара, он и представници Сабора одређују дан када би требало да се током целе ноћи читају молитве и онда наредног дана после још једне војне параде почине Сабор са радом. Најпре би комесар, са својим и народним (саборским) секретаром и епископима проверио посланичка пуномоћја, која би била уписана у посебан протокол. Потом би уследило призивање Светог духа од стране епископа. После овог чина Сабор се захваљује комесару на дозволи за држање и отварању сабора, на шта им комесар одговара својим говором у којем објављује правила или царска наређења, после чега рад Сабора и званично почиње читањем царског рескрипта од стране комесара. Он тада објављује сабору да слободним гласањем (,...per Vota libera...“) бира митрополита и за то му оставља онолико дана колико му је потребно (...und giebet ihnen so viel Tage dazu als vonnöthen ist.), мера која није поштована ни на овом, нити на наредним изборним саборима. По избору новог митрополита комесар одређује дан и време када ће бити инсталиран. ${ }^{36}$ У коначном, немачком тексту нема помена о тужбама, али у српској варијанти је одређено да се после инсталације митрополита саставља меморијал за владара ради издавања његове конфирмационе дипломе, а потом народ предаје своје тужбе које комесар прима и подноси Двору. ${ }^{37}$ Иако ова одредба није нашла своје место у коначном саборском устројству она је у de facto поштована, а чини се да је овакво решење прихватио комесар јер је већ на Сабору 1749. по њему поступано. $^{38}$

О томе шта се дешавало следећег дана и да ли је уопште било саборских седница данас се ништа не зна, у Саборском протоколу коју нема ни једног документа под датумом 13/24. јул 1749. али то не искључује могућност да се тог дана гласало о будућем митрополиту. Први документ који се помиње после 23. јула,

\footnotetext{
${ }^{34}$ АСАНУК, МПА „А“ 350/1749; Јохан Хајнрих Швикер, Политичка историја Срба у Угарској, Нови Сад-Београд 1998, 185; Димитрије Руварац, Српски Народни Сабор 1749., 121.

35 У самом документу нигде није назначено како се дочекује комесар, већ је уписано само да га дочекују са војном парадом епископи и представници сва три сталежа. (Димитрије Руварац, Српски Народни Сабор 1749., 121.)

${ }^{36}$ Димитрије Руварац, Српски Народни Сабор 1749., 121.

37 АСАНУК, МПА, „А“ 350/1749; Димитрије Руварац, Српски Народни Сабор 1749., 121; Милутин Јакшић, Два српска сабора, 174-175.

${ }^{38}$ АСАНУК, МПА „А“ 350/1749; Димитрије Руварац, Српски Народни Сабор 1749., 121.
} 
је од 25. јула и доноси информацију у једној реченици да је за митрополита изабран слободним гласањем, дотадашњи карлштадски владика Павле Ненадовић. Овако кратка белешка пружа још више могућности да се помисли како је све договорено дан раније, а 25. саопштено комесару. Избор су својим потписима потврдили представници саборских сталежа, тако се у име епископа потписао владика Висарион Павловић, у име свештенства и монаштва бездински архимандрит Теодосије Веселиновић, у име Војне границе пуковник Атанасије Рашковић, а у име Провинцијала сомборски капетан и сенатор Јован Живојиновић. Запис о овоме је оставио Јохан Берг, комесаров секретар, пред којим су се посланици потписали на своју одлуку. ${ }^{39}$ Нешто даље у протоколу стоји забележено да је народ уз пуно весеља и вике (одобравања) у цркву допратио новог митрополита објављујући његов избор. ${ }^{40}$

За Павла Ненадовића Милутин Јакшић је тврдио да је премештен са Карлштадске епископије у Арад управо из разлога што се очекивало да он буде следећи митрополит. Међутим, данас је познато да он никада није ни прешао, нити добио потврду да може прећи у Арад. Овоме у прилог иде и чињеница да је Синод од 1/12. марта поверио му администрацију ове епископије, али Јакшићева тврдња да би он могао бити следећи митрополит, није без основе. ${ }^{41}$ Да је ово очекивано сведочи чињеница да је већ за претходног сабора управо он био главни противкандидат Исаије Антоновића, иако се то из саборског протокола не види јасно, већ се чини да је владика Висарион Павловић главни Исаијин противник. Чини се како је избор протекао без икаквих проблема, односно да је, како је Јакшић запазио епископ Павле био кандидат и Двора и народа. Да је био народни кандидат у то не може бити сумње, а наклоност Двора могао је стећи у две деценије дугом стажу преговора и интезивних односа са властима у Бечу. Јакшићева тврдња у вези са прихватљивошћу Ненадовића по Бечки двор утолико је тачнија ако се види да је комесар вољу Сабора брзо прихватио и објавио. Очигледно је да је имао дозволу да Ненадовића, ако буде изабран одмах и инсталира. Док је истовремено имао и наређење да ако неко ко не одговара Бечу буде изабран, избор не прихвати и не инсталира га. Ово се односило пре свега на владику Висариона, чији избор Марија Терезија не би прихватила и потврдила. ${ }^{42}$

Одмах иза избора епископа Павла Ненадовића за митрополита одржао је комесар краћи говор у којем је поменуо да је избор извршен са царском дозволом, истичући значај улоге коју митрополит треба да обавља. На првом месту је поменуо старање за душе верника, што је сматрано веома одговорним послом. Подсетио је сабор на обавезу верности и оданости царском двору, а онда, завршавајући свој говор, још једном честитао на избору новом митрополиту истичући предност оваквог, једногласног избора. ${ }^{43}$ Митрополит је презентован народу, а комесар је

\footnotetext{
${ }^{39}$ Димитрије Руварац, Српски Народни Сабор 1749., 123.

${ }^{40}$ Димитрије Руварац, Српски Народни Сабор 1749., 127.

${ }^{41}$ АСАНУК, МПА „А“ 314/1749.

42 Јован Рајић, Рајић, Јован, Историја катихизма православних Србаља у цесарским државама, Панчево [б.г.] 27-28; Милутин Јакшић, Два српска сабора, 176.

43 Димитрије Руварац, Српски Народни Сабор 1749., 123.
} 
затражио од Сабора да се писменим путем обрати Марији Терезији како би она издала његову конфирмациону диплому и да упути Царици још једно писмо из „материје канонског права“, али се из текста не види јасно на шта се конкретно мисли. Мада је вероватно реч о нечему о чему је требало да расправља Синод, могуће о подели и укидању епископија. ${ }^{44}$ Два дана по избору Павла Ненадовића уследила је инсталација, када је митрополит положио заклетву верности пред комесаром, на српском језику, што је комесар оверио својим потписом и печатом. Истовремено је одлучено да се упути и депутација царици како би се добила потврдна, конфирмациона, диплома. ${ }^{45}$

\section{Сабор и Синод}

Комесаровим говором од 25. јула 1749. ако би се посматрало устројство сабора његова рад би требало да је завршен. Међутим, није било тако, већ су паралелно и даље радили Сабор и Синод у зависности о чему је раправљано, при чему су на Синоду решавана пре свега питања у вези са Црквом. ${ }^{46}$ Први директан помен Синода налази се у документу од 18/29. јула 1749. а последњи од 7/18. октобра 1749. којим сви скупљени епископи („Gesamte versamlete Bischof“) дају митрополиту пуномоћ за његов пут у Беч на који иде да би се за свој избор захвалио Владарки. ${ }^{47}$ Из једног другог акта јасно је да Синод није подразумевао само учешће духовних лица, већ и световних, али да његовим седницама неким или свим, то је непознато, није присуствовао комесар. Тако је забележено да су 19/30. јула у митрополиској резиденцији под његовим председништвом састали бачки епископ Висарион, пакрчки Софроније и непознат број представника оба сталежа, која је за то одредио Сабор. Ово тело је, међутим, фигурирало као Архијерејски синод и као потписници акта, помињу се сви епископи, чак и они који нису још увек конфирмирани. Несумњиво је да су потписи стављени касније. Овај Синод је донео неколико важних одлука. Најпре да се забрањује монасима који нису поданици Хабзбуршке монархије да долазе ради купљења милостиње на њен простор. Одређен је рок од три године колико то још могу да чине синајски, јерусалимски и хиладарски монаси, ${ }^{48}$ али уз услов да после три године напусте Монархију. Три године по одласку могу поново послати неког монаха, али он мора имати уредну документацију и гаранцију шест поданика Монархије да ће новац предати манастиру који га шаље. Са овим документима морао се обратити митрополиту како би му он дао дозволу за скупљање милостиње. Наређено је да се архимандрит

\footnotetext{
44 Димитрије Руварац, Српски Народни Сабор 1749., 123-124.

45 Димитрије Руварац, Српски Народни Сабор 1749., 128-130.

${ }^{46}$ АСАНУК, МПА „А“, 355/1749, 356/1749. Тако је Синод 26. јула/6. августа 1749. издао решење по којем је гомирски архимандрит Данило Јакшић требало да преузме администрацију над Карлштадском епископијом, која је избором Павла Ненадовића постала упражњена. (АСАНУК, МПА, „А“ 360/1749.)

${ }^{47}$ У пуномоћју је стајало да изабере депутате који ће га пратити из сваког сталежа, али да они неће за свој пут добити плату. (АСАНУК, МПА „А“ 398/1749.)

${ }^{48}$ При чему је наређено јеромонаху Григорију из Хиландара за којег се каже да лута по Банату, да се одмах врати у свој манастир. (АСАНУК, МПА „А“ 357/1749.)
} 
трапезунтски одмах и трајно мора протерати са територије Карловачке митрополије, а да се пећки патријарх Атанасије II обавести о Ненадовићевом избору за митрополита. Затим, да му се отпише поводом захтева да се предју ствари пећком архимандриту које је однео патријарх Арсеније IV да ће му изаћи у сусрет, али и да му јаве да је на њих од верника Карловачке митрополије патријарх потрошио три хиљаде форинти, те да ће се пећком архимандриту дозволити купљење милостиње. На крају је донето решење поводом захтева београдског митрополита Софронија да му се да нека упражњена епископија, да то по Привилегијама ни њему нити било коме другом странцу није могуће учинити, већ да му се помогне на други начин, али не пише на који. ${ }^{49}$

Мешање комесара у рад Синода састојало се у томе што је он одредио делокруг рада овог тела, на питања битна за Двор, што није искључивло расправе, о другим, за Цркву важним темама. У упутствима је стајала одлука која је била у супротности са горе поменутом одредбом српске верзије саборског устројства о постављању администратора митрополије. Комесар је најпре тражио да се по смрти митрополита, представници народа писменим путем обрате владару ради постављања администратора и одређивања начина старања о митрополијској имовини и чекају његов одговор. Друго наређење односило се на седисвакантну Северинску (Марчанску) епископију, за коју је наређено да буде подељена између Карлштадске и Костајничке дијецезе. Треће наређење односило се на Зарандску жупанију, која треба да буде инкорпорирана у Ердељ, па се у њој у будуће забрањује визитација арадског епископа. На крају одредио је комесар да и Арадска епископија буде укинута јер је по сазнањима Марије Терезије, на основу Треће Привилегије цара Леополда I од 4. марта 1695. било седам епископија. ${ }^{50}$

У записнику Сабора нема података како су епископи реаговали на ове захтеве, али нема сумње да им се они нису свидели, нарочито политика Двора у правцу Арадске дијецезе. Већ следећег дана донето је кратко решење да се у вези Марчанске и Арадске епископије написмено ништа не одговара. Да се прихвата први захтев о постављању администратора, да се у вези Марче остаје на ставу изнетом 1744., а да се у погледу Арадске дијецезе такође поступа по решењу са Сабора из 1744. Односно, да она и Вршачко-карансебешка епископија добије свака свог епископа по смрти владике Исаије Антоновића, који је управљао обема. ${ }^{51}$ Како је ускоро уследио веома опширан писмени одговор Марији Терезији није искључено да је комесар променио одлуку сабора да ништа написмено не подносе владарки. Сабор је детаљно изложио проблем у вези са Арадском епископијом, образлажући да податак о седам епископија колико је уписано 1695. у Трећој привилегији не може подразумевати укидање Арадске, јер је то био тренутни број, који је касније новим освајањем повећан, јер у том тренутку није у рукама Хабзбуршке монархије било две епископије, Темишварске и Вршачкокарансебешке. Полазећи од чињенице на који је начин арадски епископ Исаија

\footnotetext{
${ }^{49}$ АСАНУК, МПА „А“ 357/1749.

${ }^{50}$ Димитрије Руварац, Српски Народни Сабор 1749., 124.

${ }^{51}$ Димитрије Руварац, Српски Народни Сабор 1749., 127.
} 
Антоновић под своју управу подвргао и Карансебешку епископију објашњавали су Царици да је то нелегалан начин који је Сабор 1744. прихватио, али само привемено, до смрти Исаије. Због овога није могуће прихватити укидање и припајање делова ове епископије другим, нарочито, јер је већ цар Леополд I, прихватио постојање Арадске и Темишварске епископије, када је епископу Исаији Ђаковићу призно титулу епископа Јенопољског (Арадског) и Темишварског. Дакле прихватио је постојања два владичанства иако је Темишварска епископија још увек била под Османским царством и имала свог дијецезана. У погледу Северинске (Марчанске) епископије Сабор је назначио да ће она бити подељена на начин по коме би читава била припојена Костајничком владичанству из којег би били издвојени Лика и Крбава и припојени Горњокарловачком владичанству, ${ }^{52}$ што је урађено тек на следећем Архијерејском синоду 18/29. јуна $1750 .{ }^{53}$

Сабор је 29. јула донео одлуку да се изабере један одбор који ће бринути о народним пословима. У овај одбор су поред новоизабраног митрополита Павла ушли још: темишварски владика митрополит Георгије, пакрачки епископ Софроније, ковиљски архимандрит Агапије (Поповић), игумани- крушедолски Леонтије (Радојчић) и грабовачки Арсеније (Теофановић, будући владика костајнички), протопрезвитери- митровачки Стефан Пешић и сегедински Арсеније Радивојевић (такође будући епископ, пакрачки, будимски и бачки), пуковник Атанасије Рашковић, потпуковник Михајло Продановић, капетани Живан Шевић, Арсеније Ђулинац и Прокопије Ђаковић, Јован Трбуховић, новосадски сенатор Лазар Рубешић, будимски биров Петар Димић, вуковарски кнез Стефан Чупић и народни секретар Павле Ненадовић. Они су одржали саветовање после кога су се заклели да до краја живота неће одати ништа од тога о чему је расправљано. Закључили су како и где треба да се чувају Привилегије, па је у том циљу донето решење да се Леополдове Привилегије и њихове старије потврде које се налазе код будимског бирова Петра Димића ту и оставе на чување (чувају их Димић и тамошња два ешкута Петар Кнежевић и Јован Милић), а да се потврде привилегија царице Марије Терезије, које се налазе код владике Висариона пренесу из Новог Сада у Карловце. ${ }^{54}$ Поред овога одлучено је да се прегледају тестаменти

\footnotetext{
52 Представници народа са те територије (гомирски јеромонах Теодор Косановић, утински свештеник Симеон Живковић, капетан Прокопије Ђаковић, кнез Михајло Савић и коњички капетан Јован Трбуховић) пристали су на укидање ове епархије и припајање њене територије околним епископијама, али су тражили враћање Марче православцима, те да се Привилегије потврде у Вараждинском генералату. (АСАНУК, МПА „А“ 513/1750; М. Јакшић, Два српска сабора, 180-184; Д. Руварац, Српски Народни..., 124, 125.)

53 У име сабора ове закључке су потписали поред новоизабраног митрополита Павла, тројица епископа: Висарион бачки, Георгије темишварски и Софроније пакрачки, затим, пуковник Атанасије Рашковић, потпуковник Михајло Продановић, сенатор Лазар Рубешић и будимски биров Петар Димић. (Димитрије Руварац, Српски Народни Сабор 1749., 126-127; Исти, Радња Архијерејског синода 1750..., 3.)

${ }^{54}$ Биров Петар Димић обавестио је 24. маја/4. јуна 1750. митрополита шта се све налази код њега, па је том приликом поменуо да се у Будиму чувају три сандука драгоцених документа и предмета. У један сандук су смештене стре српске (Леополдовске) Привилегије, затим оригинали епископских конфирмационих диплома као и копије тих привилегија, митрополијских и епископских конфирмација, које су 1732. урађене у Сент Андреји. У другом сандуку су се такође налазиле конфирмационе дипломе
} 
архиепископа и инвентари општенародних добара (покретних и непокретних) од времена патријарха Арсенија III. Одређено је и да по један представник сва три сталежа помаже митрополиту око вођења народних послова, те је тако од стране војног сталежа одређен потпуковник Секула Витковић, од грађанства новосадски сенатор Лазар Рубешић. Представник духовног сталежа мора бити у звању епископа посвећења, који би чим се упразни нека епископска катедра постао дијецезан, а до тада би помагао митрополиту. Када постане дијецезан бирао би се нови епископ посвећења. Први се на овом положају нашао митрополијски егзарх, раковчки архимандрит Синесије Живановић, али он није никада посвећен јер је у међувремену, на Синоду 4/15. јула 1750. изабран за арадског епископа. Митрополитови помоћници су се звали општенародни пленипотенцијари, а задатак им је био да брину о општенародним покретним и непокретним добрима и приходима митрополита осим штоле. О свему су морали да имају рачуне и да их подносе митрополиту, Синоду, клеру и народу. Ништа нису могли да раде без знања митрополита и морали су да потписују концепте списа који су ишли Двору или дикастеријама, док је саме представке потписивао митрополит. Сваки пленипотенцијар имао је по један кључ благајне, а отварају је заједнички са митрополитом. За тај посао епископ посвећења добијао је годишње 400 ф, представник Војне границе 350 , а Провинцијала $250 .^{55}$

У склопу финансијских решења Сабора налази се одлука да је митрополиту Павлу одређено 12.000 форинти за његове и потребе двора за које није дужан да подноси рачун. Донета је и веома важна одлука да су Синод, клер и народ наследници општенародног имања, па према томе да су наследници и свих општенародних дугова, осим оних за Илирску хусарску регименту. Они се обавезују да исплате из народне благајне све дугове, па ради тога моле Марију Терезију да нареди кредиторима да чекају једну годину на капитал без интереса. Дозвољено је пленипотенцијару егзарху Синесију да ради на отплати дугова ове регименте, за шта је он именован још у време патријарха Aрсенија IV, ${ }^{56}$ али да се он не може разрезати као порез и на духовна лица. Решено је и да буду прегледани сви тестаменти и спискови покретне и непокретне имовине од времена патријарха Арсенија III и та се евентуалне неправилности или мањак истраже. Архијерејски тестаменти (митрополита и епископа) требало је да се одржавају по протоколу из $1731 .{ }^{57}$

Финансијски моменат био је битан и због отплате нагомиланих дугова претходника Павла Ненадовића на митрополијском трону, пре свега, дуга који је

митрополита и епископа, у оригинлу, затим протекционал издат владици бачком Григорију Димитријевићу 22. јуна 1713. Ту су биле и Привилегије, донације и салва-гвардије на манастир Гргетег и село Нерадин, све у оригиналу. У трећем сандуку су се налазиле сребрне ствари пренете овде из Београда по његовом поновном паду под власт Османлија. Петар Димић се заклињао да ће у тајности држати овај списак и да ће га он или његов наследник предати наследнику митрополита Ненадовића. Издавање овог списка могао је да учини и на захтев Сабора или Архијерејског синода. (АСАНУК, МПА „Б“, 8/1750.)

${ }_{55}$ Димитрије Руварац, Српски Народни Сабор 1749., 132-134; М. Јакшић, Два српска сабора, 178-180.

${ }^{56}$ АСАНУК, МПА „А“ 163/1747.

57 Димитрије Руварац, Српски Народни Сабор 1749., 132-134; М. Јакшић, Два српска сабора, 178-180. 
настао приликом стварања и издржавања Илирске хусарске регименте $1735 .{ }^{58}$ Већ 16/27. јула послато је писмо од стране Марије Терезије у којем се тражи пуномоћје за посланике који овим питањем имају да се баве, а који су у Беч стигли већ у време претходног митрополита. Сабор је два дана касније дао пуномоћје тројици представника духовног, војног и грађанског сталежа- архимандриту Синесију Живановићу, потпуковнику Михајлу Продановићу и сенатору Лазару Рубешићу. ${ }^{59}$ Ови дугови су се времном због камате увећавали и пред новоизабраног митрополита је постављен задатак његове исплате. Из тог разлога су се Сабору обратили егзарх Синесије Живановић и потпуковник Рајко Прерадовић и изнели шта су то радили пре две године у Бечу. Депутати су сматрали да се пре две године ишло и за тим да се намерно народ оптерети великим каматама. Тражено је да од дуга буде одбијена зарада која је добијена када су продати коњи, оружје, одећа и заставе пукова, затим, да буду враћени дугови које нису вратили официри. Сабор је сматрао да камату не може плаћати народ, јер за то нема разлога, а да није исплаћен до сада јер је фонд који је за то основан пропао. Наиме у овај фонд је требало да официри у зависости од свог чина уплаћују одређене таксе, али до овога није дошло, напротив, дугови су се увећавали јер је на једно место постављано по два официра. Због свега овога требало је да депутати траже да народ буде ослобођен камате, јер је до ње дошло злоупотребама. ${ }^{60}$ Међутим, једино што су кредитори нудили било је смањење камате са 6 на 4 \%. Са овако смањеном каматом једна бечка комисија израчунала је да главница дуга износи 67.000 форинти, а камат од 4\% за 13. година још 28.760 форинти, што је укупно чинило дуг од 95.760 форинти. Против овако великог дуга протествовао је највише у комисији архимандрит Синесије, али његови протести нису наишли на добар пријем, већ су, по његовом сведочењу, још разљутили чланове Комисије. ${ }^{61}$

На овом Сабору дошло је и до једног преседана, наиме већ од раније постојала је жеља да учитељ и проповедник, образовани јеромонах Дионисије Новаковић буде постављен за епископа у некој дијецези. На сабору држаном 1748. тражили су посланици из Вараждинског генералата да се он постави у Северинској епископију за владику, али је комесар барон Енгелсхофен поновио раније донету наредбу да то није могуће, јер је 1744. на Сабору предвиђено да ова епископија буде укинута. Када су будимски, сентандрејски и пештански посланици кренули 1748. на сабор они су већ у рукама имали захтев да се њихов учитељ и проповедник посвети за епископа. Није тада требало да буде будимски епископ, јер је у то време још био жив тамошњи владика Василије. Притисак Будимаца био је толико снажан, да је сабор још пре избора архиепископа одлучио да се бира Дионисије за владику без обзира на то ко буде изабран за митрополита. Међутим, када је 7. децемра 1748. умро владика Василије Димитријевић виђенији људи из његове епархије свега пет

\footnotetext{
${ }^{58}$ Исидора Точанац, Српски народно-ирквени сабори..., 237-243.

${ }^{59}$ АСАНУК, МПА „А“ 354/1749.

${ }^{60}$ АСАНУК, МПА, ,А“ 353/1749.

${ }^{61}$ АСАНУК, МПА, ,А“ 353/1749.
} 
дана касније затражише да за новог епископа буде постављен Дионисије. ${ }^{62}$ Не чекајући Синод ни Сабор Будимци су се представком обратили Марији Терезији тражећи да се њихова епархија попуни избором Дионисија Новаковића за епископа. Шта више одредили су депутацију која би требало да иде у Беч и да траже потврду и конфирмацију Дионисија. Митрополиту Исаији је 4. јануара 1749. јављено од стране Илирске дворске депутације шта је тражено уз речи да је неопходно испоштовати процедуру јер се по Привилегијама прво бира епископ, којег потом митрополит презентује владару ради потврде. Суштина је била да Двор није имао ништа против Дионисија и његовог постављања за будимског епископа, већ да је од митрополита тражио формалну процедуру, дакле да га формално презентује, што значи да се у супротности са дотадашњим правилима сложи са одлуком будимских епархиота и да је прихвати, због чега му и пишу. Међутим, пар дана касније умро је митрополит Исаија, те од ове акције није било ништа. Једино је владарка преко Илирске дворске депутације потврдила Дионисија за администратора, у време док је и митрополијски трон био празан, сматрајући да не може бити изабран нити потврђен за епископа пре митрополијског избора, што је и добро, јер док се све око митрополијског избора не обави показаће се какав је Новаковић и да ли заслужује да буде епископ, сматрала је Царица. ${ }^{63}$

На састанку одржаном пре отварања Сабора из 1749. како је то већ речено, обавезао се Сабор да ће Дионисија по избору митрополита посветити за епископа, без обзира на то ко буде нови митрополит, ${ }^{64}$ што је било у складу са одлуком претходног Сабора. По Нендовићевом избору били су код барона генерала Хелфрајха пуковник Атанасије Рашковић, потпуковници Михаило Прерадовић, Јован Хорват и Секула Витковић да траже од њега да се Новаковић рукоположи за епископа. Комесар је то дозволио јер Привилегије то дозвољавају, али је оставио могућност да митрополит Павле због тога одговара, јер му је била позната жеља Двора да се са дотадашњом праксом прекине и да епископ без претходног прихватања од стране владар не може бити хиротонисан. Своју вољу, а ради сигурности митрополита Павла посведочили су тада писмено набројани српски официри. Тако је 23. јула/3. августа митрополит Павле хиротонисао Дионисија за епископа будимског, али царска конфирмација није брзо стигла. Најпре је после Синода из 1750. који је сасвим је извесно потврдио Дионисијев избор Царица то прихватила и 5. септембра послала о томе писмо преко Илирске дворске депутације митрополиту Ненадовићу. ${ }^{65}$ А потом је 5. новембра 1750. стигла и конфирмација за новоизабраног епископа. ${ }^{66}$ Међутим, сви поступци у вези са Новаковићевим избором навели су Марију Терезију, да осуди поступак Будимаца и изда наређење

\footnotetext{
${ }^{62}$ Гаврило Витковић, Споменици из Будимског и Пештанског архива, Збирка трећа, Београд 1874, 116118.

${ }^{63}$ АСАНУК, МПА, „Б“, 27/1749.

${ }^{64}$ АСАНУК, МПА, „А“ 348/1749.

${ }^{65}$ АСАНУК, МПА „А“ 556/1750.

${ }^{66}$ Секретар митрополије је у протокол записао да је Марија Терезија Царица и Краљица „...mittelt dem König: Hungar. Hof. Kanzley confirmiren den Dyonisium Novakovich zum Bischofen zu Ofen, Stulweissenburg, Szigeth und Mohacs...“ (АСАНУК, МПА „А“ 599/1750.)
} 
по којем се због њиховог понашања одређује да приликом наредног сабора будимски посланици на њему не могу присуствовати. ${ }^{67}$

Питање школа, њиховог отварања и издржавања било је нерешено још од Велике сеобе 1690. Иницијативе појединаца, пре свега митрополита и понеког епископа, најчешће су биле ограничене на време њихове управе епископијом или митрополијом, осим у случају Рождествено-богородичне школе бачког владике Висариона, која је надживела свог оснивача. Српске средње школе радиле боље само под утицјем руских учитеља у време митрополита Мојсија Петровића и Вићентија Јовановића (1726-1737). Управо тада надзирали су њихов рад двојица будућих митрополита, Исаија Антоновић и Павле Ненадовић. Обојица Будимци којима се пружила могућност да се у детињству образују и преко просветитељских идеја схвате значај образовања, ${ }^{68}$ одмах су по свом избору дали иницијативу за побољшање српског школства. Митрополит Исаија је у том циљу учинио прве кораке позивајући вернике и свештенство да дају прилоге за један фонд за издржавање школа. ${ }^{69}$ Док је Антоновић амбициозно кренуо у ову акцију желећи прилоге из свих епархија, Сабор је 10/21. августа 1749. донео одлуку која је била знатно конкретнија у погледу скупљања прилога, при чему је ограничена на простор Архидијецезе. ${ }^{70}$ Одређено је одмах ко и колико би требало да прилаже у фонд. Међу приложницима су били митрополит, фрушкогорски манастири, протопрезвитери у архидијецези, свештеници, све црквене општине, приликом руополагања за презвитера и ђакона кандидати су давали прилоге за овај фонд, затим је одређено да се из цркава у Архидијецези уклоне кутије за прилоге манастирима изван Хабзбуршке монархије и на њихово место ставе школске кутије, а свештеници су имали да се старају да људи у њих прилажу приликом свадби, сахрана или славља. Одмах су одређени школски тутори, односно стараоци школског фонда: реметски игуман Атанасије, митровачки протопрезвитер Стефан Пешић, свештеник Јефтимије Радосављевић, пуковник Атанасије Рашковић и управник поште Андреј Андрејевић. Они су приход предавли школском економу који је увек морао бити из Карловаца, а на Сабору је одређено да то буде Јован Матић. Средстав у фонду су брзо пристизала јер су у њега прилагали не само одређени на Сабори већ и многи други појединци, нпр. сви епископи. ${ }^{71}$ Тако је настао најстарији фонд у Карловачкој

\footnotetext{
${ }^{67}$ J. Х. Швикер, Нав. дело, 103-104.

${ }^{68} \mathrm{O}$ прихватању просветитељских идеја у погледу образовања најречитије говоре пастирске посланице митрополита Ненадовића. (Архив Српске акаемије наука и уметности (у даљем тексту АСАНУ), 12176 , Посланице од: 15/26. јула 1750, . јануара/11. фебруара 1753, Посланица од 13/24. маја 1754, 17/28. октобра 1755, 25. септембар/6. октобар 1759, 19/30. октобра 1761, 26. септембра/7. октобра 1763, 24. септембра/5. октобар 1764.)

69 Димитрије Руварац, Позиви и одзиви или радња појединих српских архиепископа у митрополији Карловачкој, око подизања српских школа и стварања фондова за њихово издржавање, Земун 1894, VII, 4-9.

${ }^{70}$ Милош Рајић износи тврдњу да је фонд основан због карловачких школа, те да је то разлог зашто је митрополит рачунао само на прилоге из Архидијецезе. (Милошъ Раићъ, Србски народни фондови, Карловци 1864, 4-6.)

${ }^{71}$ Димитрије Руварац, Позиви и одзиви..., 9-18.
} 
митрополији - Клирикални фонд, ${ }^{72}$ који је у време смрти митрополита Ненадовића као основу имао 33.944 форинте сребра. ${ }^{73}$ Акција Сабора и митрополита која је почела прикупљањем средстава, настављена је у јесен исте године када је митрополит у Карловцима отворио Покрово-богородичне школе.

На пољу духовног рада Сабор, Синод и новоизабрани митрополит донели су значајно решење које се тицало сремских манастира и општежића у њима. Реч је била о монашким правилима митрополита Вићентија Јовановића, донетим 1733. Митрополит Ненадовић додао је овим правилима осам нових параграфа за које је сматрао, на основу личног искуства, да би их требало увести. Искуство је стекао, како је то истицао у уводном тексту своје наредбе, управо у време митрополита Вићентија обилазећи сремске манастире. Тако је најбоље схватио пороблеме са којима се среће монаштво. Доношење овог акта био је тек почетак у дужој борби које је митрополит током своје управе Карловачком митрополијом водио са монаштвом сремских манастира, како би у потпуности њихов живот био посвећен духовном пољу. ${ }^{74}$

Једна од првих акција новоизабраног митрополита било је решавање случаја протопрезвитера Николе Поповића из Велике Писанице. ${ }^{75}$ Он је држан у притвору још од времена патријарха Арсенија IV. Патријархова смрт омела је изношење тужбе те је цео посао одгођен до избора новог митрополита. Али кратка Исаијина управа није стигла да реши ово питање, па је протопрезвитер остао у притвору све до избора Павла Ненадовића. Већ 27. јула/7. августа митрополит је донео решење по којем се протопрезвитер ослобађа јер није познта никаква његова кривица, шта више, познатије су заслуге за православну цркву, јер је у свом родном месту подигао парохијски храм и школу. Митрополит је сматрао да неправедно затварање мора некако да се надокнади те је одредио да Никола Поповић одмах по пријему овог решења оде у манастир Лепавину где би требало да га замонаше и у најкраћем могућем року да прође сва звања до архимандритског са правом да контролише свештенство у свом дотадашњем протпрезвитерату. Звање које је добио протопрезвитер Никола морало му је остати до краја живота, а његова породица

\footnotetext{
${ }^{72}$ Први назив овог фонда био је Касе Покрово-Богородичних школа Архиепископије Митрополије, из чега је могуће закључити да је прва намена фонда била да издржава Покрово-богородичне школе у Карловцима. Основна намена је брзо измењена па је фонд служио у знатно шире сврхе. (Димитрије Руварац, Покрово-богородичне школе у Карловцима (1749.-1769.), Сремски Карловци 1926, 5.)

${ }^{73}$ Фонд је током управе митрополита Ненадовића имао укупно 52.176 форинти сребра, од чега је сам митрополит дао 11.174 форинте сребра. За плате учитеља Покрово-богородичних школа и школске потребе утрошено је до 1768. 18.232 форинти сребра. Коначан изглед и начин доласка прихода овог фонда уређен је тек по Ненадовићевој смрти на захтев Двора. (Славко Стеф. Видаковић, Постанак $u$ развитак срп. народно-ирквених фондова и фундачија у Сремским Карловиима, Нови Сад 1922, 10-14.)

${ }^{74}$ АСАНУК, МПА „Б“ 46/1749.

${ }^{75}$ Он је још на црквено-народном сабору из 1726. добио извесна епископска права над православцима у Вараждинском генералату јер се побуном одметнуо од јурисдикције унијатсог марчанског епископа. У споразуму са костајничким владикама он је вршио ту дужност све до 1735. и постављања Симеона Филиповића за марчанског православног епископа, као и после Филиповићеве смрти 1743. до 1746. Када се замонашио добио је име Нићифор. (Радослав М. Грујић, Пакрачка епархија историјско-статистички преглед, Београд 1996, 107-108.)
} 
докле буде давала свештенике имала је специјалан статус по којем би ови свештеници увек имали право на парохију проте Николе. Овакав „Устав“, како га је назвао митрополит Ненадовић, морао је бити акт обавезујући за све епископе у саставу чије епархије је Николин протопрезвитерат, као и за све митрополите. ${ }^{76}$ Митрополит свој став према Николи Поповићу није изградио само на основу личних симпатија, већ пре свега на основу сведочанстава људи, духовног и војног сталежа који су припадали његовој парохији, укупно 55 особа, од којих је најзначајнији по звању био пуковник Михајло Микашиновић од Шлагенфелда. ${ }^{77}$

\section{Тужбе}

Тужбе и жалбе на разне злоупотребе, биле су саставни део и овог Сабора. Како је то предвиђао саборски протокол оне су требале да буду предате комесару после митрополијске инсталације у време када је писан меоријал за владра у коме је Сабор молио конфирмациону диплому. Свакако да је на Сабору, али што је још вероватније између званичних саборских седница, било разговора о проблемима са којима се српски народ сусреће. Како је изборни сабор 1749. радио мање од годину дана после претходног тужбе су биле сличне. Оне нису поднете све у исти дан, већ у дужем периоду, од 18/29. јула до 1/12. авгута, при чему је пакрачки епископ поднео митрополиту још једну тужбу тек у октобру $1749 .{ }^{78}$

Између осталих тужили су се 18/29. јула 1749. посланици на неправде које се чине у Бихарској области, у местима Беленошки, Белски, Брзокришком, Лунки и Бистри, у име којих је изнета тужба да немају свог епископа који би водио бригу о њиховом духовном животу, а да се налазе у лошем стању, те страхују од покушаја унијаћења. Представници ове области су у вези са овим изнели на прошлом Сабору своју тужбу, а сада је понављају. Свештенство из Бихарске жупаније је овде застрашено судбином двојице свештеника Георгија и Јована који су држани оковни у тамници, где су мучени, због чега је поп Јован, четврти дан по изласку из тамнице, умро. Зато су молили Сабор да преко комесара и лично код цара и царице моле да им буде постављен православни епископ који би водио бригу над њиховим духовним животом и који би имао право редовне канонске визитације својих црквених области. ${ }^{79}$

Унијаћење је било основа тужбе коју су Сабору поднели Стојан Петровић и Ђурка Аради. Они су, такође, истакли да су исту тужбу поднели и претходном

\footnotetext{
${ }^{76}$ АСАНУК, МПА, „Б“ 45 I/1749.

77 Њихово сведочанство се односило на одбрану не само протопрезвитера Николе већ и указивање на значај његове породице, за српски народ у вараждинском генералату, говорећи о оцу и брату који су били свештеници и браћу, Гаврилу и Томи, који су били у војној служби, Истакли су нарочито заслугу проте за борбу против уније при чему није презао да се у име поштовања Привилегија обрати ни самом цару Карлу VI. (АСАНУК, МПА „Б“, 45 II/1749.)

${ }^{78}$ АСАНУК, МПА „А“ 355/1749, 356/1749, 358/1749, 31/1749,362/1749, 365/1749. и АСАНУК, МПА „Б“ 43/1749.

${ }^{79}$ Ову тужбу су потписала тројица свештеника Алексије и Петар Гавруца у име Белоношког и Белског дистрикта и Петар Дромба у име Брзокрижког, Лунке и Бистре. (АСАНУК, МПА, „А“ 356/1749.)
} 
сабору 1. септембр, али да су, пошто се ништа до сада није променило, дужни да је понове. Православне у Великом Вараду официри присиљавају на унијаћење, док их коморски директор Сигисмунд Мартоноши и инспектор Ђорђе Токоди присиљавају да за епископа прихвате унијатског владику Мелетија Ковача. Од овог притиска се нису могли да одбране те су званично прихватили унију, али нити су ишли у унијатске цркве нити су мислили да буду искрени унијати. Када је Мелетије Ковач затражио да се писменим путем обавежу да прелазе на унију, а они то одбили, одузели су им на силу цркву. При томе су пароха Петра који је чувао кључеве цркве затворили и нису га пуштали једанаест недеља, чак су га и мучили. На карају су и поред интервенције Марије Терезије да им се врати црква морали у њу на силу да уђу, због чега су официри са војницима нељудски пребили свештеника и голог и босог га мучили неколико дана у тамници, где се још увек налази. Посланици су тада затражили од Сабора да им свештеник буде пуштен и да на онову Привилегија то захтева и Сабор, али и да као трајно решење добију једног православног епископа јер се само тако могу спасти од унијатских напада. ${ }^{80}$

Сегедински депутат Василије Лаушевић поднео је Сабору тужбу у име српске сегединске општине. Он се жалио да се у последњих пар година присиљавају православци Сегедина да славе римокатоличке као и своје празнике и да им је у те дане забрањена свака врста посла. Због овога пре свега трпе православне породице и царска каса јер су у финансијском губитку, те Лаушевић предлаже да се о овоме Сабор обрати владарки, а да она пише сегединском команданту како би православни верници били од ових злоупотреба заштићени, у складу са Привилегијама. ${ }^{81}$

Из Темишвара су такође стигле многе тужбе, које су сабору поднела тројица посланика, темишварски протопрезвитер Арсеније Исаковић, липовски протопезвитер Христофор Војинов и темишварски биров Јовица Стајић. Прва жалба је била упућена због забране да се православни свештеници пуштају код православних осуђеника на смрт. Они су изнели ранију праксу да су православни свештеници одлазили три дана пре извршења смртне казне код осуђеника где би га иповедали и причестили и на дан погубљења га пратили кроз град на губилиште. Међутим, пракса је сада до те мере измењена да се православним свештеницима само дозвољава да на губилишту изван града дочекају осуђеника, којег прате католички свештеници. Друга њихова тужба је била финансијске природе и жалили су се што свештеничке породице нису ослобођене контрибуција, подвоза и осталих дажбина, као што су католички свештеници. ${ }^{82}$

Исти финансијски моменат био је и повод тужбе будимских посланика. Они су изложили да православне присиљавају на унију и да им отимју цркве, а забрањују подизање нових. Такође, указали су како у Острогону Србе не примају у мајсторске цехове, а забрањују им и куповину непокретне имовине. Будимци су се жалили не само на католичку цркву већ и на представнике цивилне власти који им

\footnotetext{
${ }^{80}$ АСАНУК, МПА, „А“ 356/1749; 361/1749. и 364/1749; Милутин Јакшић, Два српска сабора..., 315-316.

${ }^{81}$ АСАНУК, МПА „А“ $358 / 1749$.

${ }^{82}$ АСАНУК, МПА „А“ 365/1749; Милитин Јакшић, Два српска сабора.., 316.
} 
се не дозвољавају, као што је до тада био обичај, да приликом сахране православног верника у виду литије иду кроз место. Ово им је онемогућено у Стоном Београду и Ђуру. Градња цркве им је забрањена у Мохачу и Сечују, а заустављена у селу Брему у Барањи. ${ }^{83}$

Посебном тужбом, Сабору, Синоду и митрополиту обратили су се сремски манастири, који су указали како њихова имовинска права узурпирају чиновници са Одескалкијевог спахилука. Они су се тужили да спахијски поданици сеју на манастирској земљи и да секу манастирске шуме. Сукоби су повремено били жестоки, па је долазило и до физичког обрачуна или до затварања појединих монаха. ${ }^{84}$

Значајна је и тужба коју је у име Пакрачке епископије поднео њен епископ Софроније Јовановић 21. септембра/2. октобра 1749. На основу записа на њој види се да није настала на Сабору или пре њега, већ управо у септембру 1749. те иако није била међу осталим тужбама, обавезивала је митрополита да и са овом тужбом упозна владара и Илирску дворску депутцију. Тужба се односила на однос према православцима у Пожешкој жупанији, нарочито у Сирачу, где су православце ноћу по наредби официра „пандури“ пљачкали, а куће им спаљивали. Епископ Софроније се о овоме већ тужио владару када је после смрти митрополита Исаије боравио у Бечу. Тада је и добио усмено обећање Фердинанда фон Коловрата да не морају слушати никог од „Хрвата и Мађара“ који им долазе, ако на документу немају његов потпис, али епископ закључује, то за њих нема никакво значење, јер не уважавају ни самог Коловрата, те и даље трпе невоље, нарочито од администртира сирачког доминијума Антонија Дијаковића. Епископ је сматрао да је митроплитова обавеза да о овоме упозна владара и да разговара са њима како би православни српски народ био заштићен. ${ }^{85}$

\section{Одлука о српским захтевима или уместо закључка}

О српским захтевима упућеним са Сабора 1749. расправљало се пре 4. фебруара 1750. када је преко Илирске дворске депутације Марија Терезија јавила митрополиту шта је решено у погледу захтева и намера донетих на последњем црквено-народном сабору. Опширни текст „министарства за српска питања“ донело је решења за четири питања, Марчанску епископију, Арадско владичанство, питње посвећења и потврде епископа и питање митрополитовог одласка у Беч одмах после изборног сабора. До ових решења се дошло на основу текста које је са Сабора доставио владарки њен комесар Хелфрајх, те личних контаката и разговора између њега, митрополита и Илирске дворске депутације. Тако је решено да без одлагања Марчанска епископија буде подељена тако да њена територија уђе у састав две са њом граничне епископије, Костајничком и Карлштадском, што има бити учињено без одлагања на Синоду који митрополит мора сазвати одмах по

\footnotetext{
${ }^{83}$ АСАНУК, МПА „А““ 362/1749; Милитин Јакшић, Два српска сабора..., 315-316.

${ }^{84}$ Милитин Јакшић, Два српска сабора..., 317.

${ }^{85}$ АСАНУК, МПА „Б“, 43/1749.
} 
повратку из Беча. У вези Арадске епископије донето је решење по којем оно и даље остаје епископија. ${ }^{86}$

Одлука о времену посвећивања (хиротоније) епископског кандидата, његове презентације владару и прихватања заузимала је посебно место у објашњењу владарких закључака. На ову меру царица Марија Терезија одлучила се после догађаја у вези са Дионисијем Новаковићем, а текст који је донет у решењу српских захтева имао је снагу закона. У објашњењу одлуке наведено је да Марија Терезија не жели да оспори митрополитово право посвећивања-Ius Consecrandi Episcopos, али да постоји и право владара да потврди избор епископа, по којем епископ не може бити хиротонисан пре него што буде презентован и потврђен од стране Двора. У супротном, сматрала је Царица могло се десити да владар хиротонијом буде стављен пред свршен чин. У случају да владар не жели из неког разлога да прихвати избор епископског кандидата, а да је он за то звање већ хиротонисан, то би значило да особа која има звање епископа, не може добити дијецезу и принадлежности које му тиме припадају. Да се ово не би десило, а владарско право потврде било поштовано, решено је да тек по прихватању епископског кандидата од стране владара он може бити посвећен за епископа. ${ }^{87}$

Четврто решење тицало се митрополијског избор, односно обавезности путовања новоизабраног првојерха у Беч где би се лично захвалио владару на потврди. Ово је имало и изузетан политички значај јер би био успостављен непосредни контакт између Двора и новог митрополита, а свакако би му у Бечу била саопштена очекивања у погледу његовог држања или у погледу његових верника. Таква мера морала је бити значајна пре свега код оних митрополита који су као епископи имали мање контаката са Двором, што са митрополитом Ненадовићем није био случај.

О жалбама у вези са повредама привилегијалног српског статуса није било ни једне речи у овом решењу, а исти проблеми наставили су да муче Србе у наредном периоду још интензивније. ${ }^{88}$ Митрополит Ненадовић је имао у овим тужбама добру основу за наступање ка Бечу, али је пракса потврдила да се у скоријој будућности ништа није мењало у позитивном смислу. Енергична особа, са завидним искутвом у односима са Двором, локалним властима и католичком црквом, какав је био митрополит Ненадовић, реаговао је тако што је у виду Тужбе и Меморијала из јесени 1751. поново нагласла неправде које се чине његовом народу. Није се митрополит зауставио само на писменом обавештењу, већ је све тужбе и усмено пренео владарки, а писмени облик послао на низ адреса најутицајнијих људи у Монархији. Његове тужбе највише су се заснивале на доказима о кршењу Привилегија које му је доставио пакрачки владика Софроније и арадски Синесије. Из њих се види да не само да није одговорено на тужбе упућене са Сабора 1749. већ да су проблеми радикализовани. Тако је питање непоштовања јулијанског каленара,

\footnotetext{
${ }^{86}$ Димитрије Руварац, Српски Народни Сабор 1749., 134-135.

${ }^{87}$ Она се у решењу директно и позива на случај са епископом Дионисијем. (Димитрије Руварац, Српски Народни Сабор 1749., 136.)

${ }^{88}$ Димитрије Руварац, Српски Народни Сабор 1749., 134-136.
} 
односно питање присиљавања православних верника да не раде и на католичке празнике свој епилог добило тек после опширне Ненадовићеве тужбе из 1751. услед чега је донето решење 20/31. октобра 1752., на основу старије праксе, да православци не смеју радити само на четири католичка празника, Божић, Ускрс, Духове и Брашанчево. ${ }^{89}$ Друге тужбе, пре свих питање не прихватања православаца у цеховска удружења, глобљење свештентва и забрана градње цркава и дање су остале актуелне, чак нису решене ни по митрополитовом захтеву из јесени 1751. Шта више, на територији Хрватске и Славоније унијаћење је добило нови замах, док су сталежи покушавали да оснаже, истина безуспешно, старе дискриминаторске законе уперене против Срба. ${ }^{90}$

\section{Извори и литература:}

Извори:

Архив Српске академије наука и уметности, 12176, Циркуларни протокол 1750-1767.

Архив Српске академије наука и уметности у Сремским Карловцима, Митрополископатријаршиски архив (АСАНУК, МПА), фонд „А“ и „Б“.

Литература:

Видаковић, Славко Стеф. Постанак и развитак срп. народно-ирквених фондова и фундащија у Сремским Карловиима, Нови Сад 1922.

Витковић, Гаврило, Споменици из Будимског и Пештанског архива, Збирка трећа, Београд 1874.

Гавриловић, Владан, Темишварски сабор и Илирска дворска канщеларија (1790-1792), Нови Сад 2005

Грбић, Манојло, Карловачко владичанство, Друга књига, Топуско 1990.

Грујић, Радослав М, Пакрачка епархија историјско-статистички преглед, Београд 1996.

Јакшић, Милутин, Два српска сабора (1748 и 1749), Богословски гласник, Књига I, Сремски Карловци 1902.

Јакшић, Милутин, Д. Рувараи, Српски Народни Сабор 1749. Споменик Срп. Краљ. Академије LXII, 1925. (приказ), Гласник историјског друштва у Новом Саду, Књига I, Свеска I, Нови Сад 1928.

\footnotetext{
${ }^{89}$ АСАНУК, МПА „Б“ 117/1751; АСАНУ, 12176, Посланица од 20/31. октобра 1752.

${ }^{90}$ Хрватски сталежи су на Дијети тражили да Марија Терезија нареди извршење 46. законског чланка из 1741. којим се потврђују раније донети закони за Славонију и Хрватску у циљу очување католичке вере, по којима су само католици на овој територији имали право да стичу непокретности. Сталежи су тражили да се спречи градња православних цркава и обраћање католика или унијата у православну веру. Захтевали су одузимање сваке власти патријараха̂, митрополитаิ и епископа на подручју Хрватске, Далмације и Славоније, те протеривање епископа из Пакраца, Костајнице и Плашког, чак иако за то место имају царску потврду. (АСАНУК, МПА „Б“ 117/1751. и 122/1751; Манојло Грбић, Карловачко владичанство, Друга књига, Топуско 1990, 25-26; Ј. Х. Швикер, Нав. дело, 76-77; Симеон СимеоновићЧокић, Српске привилегије, Војводина, књига II, Нови Сад 1939, 68-69).
} 
Кашић, Душан Љ, Посланици на нродно-ирквеном сабору 1749. у Карловичима, Зборник за историју Матице српске, књига 2, Нови Сад 1970.

Микавица, Дејан, Гавриловић Владан, Васин Горан, Знаменита докумнта за историју српског народа 1538-1918, Нови Сад 2007.

Микавица, Дејан, Политичка идеологија Светозара Милетића, Нови Сад 2006.

Микавица, Дејан, Српско питање на Угарском сабору, Нови Сад 2011.

Рајић, Јован, Историја катихизма православних Србаља у иесарским држсавама, Панчево [б.г.]

Раићъ, Милошъ, Србски народни фондови, Карловци 1864.

Руварац, Димитрије, Дозвола за држање народног сабора 1749. Српски Сион, број 16, Сремски Карловци 1906.

Руварац, Димитрије, Позиви и одзиви или радња појединих српских архиепископа у митрополији Карловачкој, око подизаға српских школа и стварања фондова за юихово издржаваъе, Земун 1894.

Руварац, Димитрије, Покрово-богородичне школе у Карловиима (1749.-1769.), Сремски Карловци 1926.

Руварав, Димитрије, Српски Народни Сабор 1749., Споменик Српске краљевске академије, LXII, други разред, 51, Земун 1925.

Руварац, Димитрије, Српски народни и ирквено-народни сабори у Угарској и и. к. и к. повереници на ьима од 1690 до данас, Земун 1889.

Симеоновић-Чокић, Симеон, Српске привилегије, Војводина, књига II, Нови Сад 1939.

Точанац, Исидора, Српски народно-ирквени сабори (1718-1735), Београд 2008.

Швикер, Јохан Хајнрих, Политичка историја Срба у Угарској, Нови Сад-Београд 1998. 
NENAD NINKOVIĆ

\title{
THE CHURCH-NATIONAL ASSEMBLY AND THE SYNOD OF BISHOPS FROM 1749
}

\begin{abstract}
Summary
After the death of Metropolitan Isaije Antonović on 22 January 1749, the throne of Karlovci Metropolitanate remained vacant again, only after five months. Bishops immediately began to prepare the new Church-National Assembly, deciding to entrust the administration for the third time, at the time of sedysvacant, to the Bishop of Bačka, Visarion Pavlović. The Imperial Commissioner Baron General Christian von Helfrich, opened the Assembly on 23 July 1749, and two days later there was elected the new Bishop of Karlovci, Carlstadt Bishop Paul Nenadović. In addition to the election of Metropolitan, the Assembly passed a number of useful decisions for the Serbian people, for example, the Clerical fund was established, the monastic rules of the Metropolitan Vićentije Jovanović were strengthened, and the first Assembly organization was brought. As it was a custom, there were brought charges which reflected the situation of the Serbian nation within the Habsburg monarchy, testifying the violation of Privileges, which were confirmed by all the Habsburg rulers from Leopold I to Maria Theresa. Resolving the issue of debts, Episcopal consecration, the right to appoint the administrator, etc. it also found its place. In parallel to the Assembly, the Synod of Bishops was working as well, which brought important decisions for the spiritual life, but also decisions regarding the issue of reduction of episcopacies.
\end{abstract}

Keywords: Church-National Assembly, Synod of Bishops, Metropolitan Pavle Nenadović, Commissioner Christian von Helfrich, Assembly structure, reduction of episcopacies, national charges. 